\title{
The elusive role of $B$ lymphocytes and islet autoantibodies in (human) type 1 diabetes
}

\author{
Stef J. Bloem ${ }^{1}$ • Bart O. Roep ${ }^{1,2}$
}

Received: 30 January 2017 / Accepted: 4 April 2017/Published online: 24 April 2017

(C) Springer-Verlag Berlin Heidelberg 2017

\begin{abstract}
The role of B lymphocytes in the pathogenesis of type 1 diabetes in humans is not entirely evident. These cells are presumed to be important, but this assumption is largely based on animal models of autoimmune diabetes, where compelling evidence for the contribution of both B lymphocytes and insulin-specific autoantibodies to this disease is in place. For humans, this is much less the case; the exact way in which B lymphocytes and/or autoantibodies may contribute to type 1 diabetes is not yet known but the possibilities include a pathogenic function ('fire'), or they may represent a surrogate of loss of immune tolerance to beta cells ('smoke') or, indeed, they could be a marker of an attempt at immune regulation ("ice water'). In this issue of Diabetologia, a study by Willcox et al (DOI: 10.1007/s00125-017-4221-7) adds new information but no greater clarity on the relevance of B lymphocytes in type 1 diabetes, showing a decrease in germinal centre frequencies in donors with recent-onset type 1 diabetes compared with control donors and donors with longstanding type 1 diabetes. These new findings may guide the research community to design experiments to unambiguously define whether B lymphocytes or their products function as fire, smoke or perhaps ice water in the immunopathogenesis of type 1 diabetes.
\end{abstract}

Keywords B lymphocytes - Germinal centre ·

Immunopathogenesis $\cdot$ Islet autoantibodies $\cdot$ Lymphoid

follicles $\cdot$ Pancreas-draining lymph nodes

Bart O. Roep

broep@coh.org

1 Department of Immunohaematology and Blood Transfusion, Leiden University Medical Center, Leiden, the Netherlands

2 Department of Diabetes Immunology, Diabetes \& Metabolism Research Institute, Beckman Research Institute, City of Hope, 1500 E Duarte Road, Duarte, CA 91010, USA

\section{Introduction}

To date, B lymphocytes have been widely considered as part of the pathogenic processes leading to type 1 diabetes, where their effects are mediated directly through antigen presentation to $\mathrm{T}$ cells and indirectly through long-term production of circulating islet autoantibodies (attributable to terminally differentiated B lymphocytes, termed plasma cells) [1]. Evidence giving a decisive answer on the role of $\mathrm{B}$ lymphocytes in the pathogenesis of type 1 diabetes in humans, however, has not yet been presented. In view of the major role assigned to $B$ lymphocytes in type 1 diabetes it is of critical importance to know their precise role and function in this disease. But what do we know for sure (Table 1)?

\section{B lymphocyte function in general and in mice}

Autoantibodies occur in many autoimmune diseases and their pathogenic roles in these diseases have been proven, with $\mathrm{B}$ lymphocyte-targeted therapy being successfully used as treatment, at least in some [2]. In the NOD mouse model of type 1 diabetes, B lymphocytes play a critical diabetogenic role [3, 4]. In NOD mice, therefore, it is 'game, set and match': it is a $\mathrm{B}$ cell disease as much as a $\mathrm{T}$ cell and beta cell disease, even though the ability of B lymphocytes to produce islet autoantibodies has been proven not to be prerequisite for diabetes to occur in NOD mice. Yet, in other mouse models of type 1 diabetes, B lymphocytes are dispensable [5].

In human disease, the function of B lymphocytes is less obvious and the desire to directly link murine pathogenesis of type 1 diabetes to that of humans (in spite of the profound differences in the immune systems between the two species) has led to various misconceptions and false expectations $[6,7$, 8]. As an example of how this can be misleading, maternal 
Table 1 Gaps in the knowledge related to B lymphocytes and the pathogenesis of type 1 diabetes

\begin{tabular}{|c|c|c|}
\hline Observation & Reality check & Opportunities/future goals \\
\hline $\begin{array}{l}\text { B cells are pathogenic in many } \\
\text { autoimmune diseases }\end{array}$ & $\begin{array}{l}\text { In human } \mathrm{T} 1 \mathrm{D} \text {, evidence for a pathogenic role for B } \\
\text { cells remains lacking }\end{array}$ & $\begin{array}{l}\text { Design experiments to unambiguously define whether B cells } \\
\text { function as 'fire', 'smoke' or 'ice water' }\end{array}$ \\
\hline $\begin{array}{l}\text { B cells are essential for diabetes } \\
\text { development in NOD mice }\end{array}$ & In other mouse models, B cells are dispensable & $\begin{array}{l}\text { Create more suitable animal models to delineate a role for B } \\
\text { cells in humans }\end{array}$ \\
\hline $\begin{array}{l}\text { B cells give rise to } \\
\text { AAbs-producing plasma cells }\end{array}$ & $\begin{array}{l}\text { Islet AAbs predict development of T1D } \\
\text { The role of these islet AAbs in disease progression } \\
\text { remains unresolved } \\
\text { Evidence that antibodies access intra-beta cell } \\
\text { targets is lacking } \\
\text { Changes in islet AAbs are not concordant with } \\
\text { efficacy of immune interventions }\end{array}$ & $\begin{array}{l}\text { Revisit or repeat immunotherapy trials targeting B cells or } \\
\text { (auto)antibodies } \\
\text { Establish relevance of anti-islet seronegativity in defining } \\
\text { T1D and whether islet antibodies are essential in T1D } \\
\text { development } \\
\text { Understand the low rate of disease manifestation in } \\
\text { seropositive individuals } \\
\text { Use longitudinal studies to see which comes first, B } \\
\text { lymphocyte autoreactivity or loss of T cell tolerance } \\
\text { Conduct systematic studies of epitope and antigen spreading } \\
\text { and its relationship to disease progression and therapeutic } \\
\text { response }\end{array}$ \\
\hline $\begin{array}{l}\text { Bregs support Treg differentiation } \\
\text { via IL-10 production }\end{array}$ & $\begin{array}{l}\text { In T1D, Bregs seem decreased } \\
\text { Transitional B cell emergence associates with } \\
\text { clinical efficacy of rituximab }\end{array}$ & $\begin{array}{l}\text { Study Bregs in T1D development and in the setting of B cell } \\
\text { depletion therapy }\end{array}$ \\
\hline $\mathrm{B}$ and $\mathrm{T}$ cells act in synergy & $\begin{array}{l}\text { Inverse correlations between islet AAbs and T cells } \\
\text { have been observed } \\
\text { Mice lack AAbs against } \mathrm{GAD}_{65} \text {, IA- } 2 \text { and } \mathrm{ZnT} 8 \\
\text { If B and T cell epitopes overlap, T cells } \\
\text { produce IL-10 }\end{array}$ & $\begin{array}{l}\text { Clarify the nature of the relationship between } \mathrm{B} \text { and } \mathrm{T} \text { cells in } \\
\text { disease and in a therapeutic setting } \\
\text { Examine whether inverse correlations point to disease } \\
\text { heterogeneity } \\
\text { Test the possibility that islet antibodies mark an attempt to } \\
\text { regulate islet autoimmunity }\end{array}$ \\
\hline $\begin{array}{l}\text { Islet-specific AAbs are directed } \\
\text { against intracellular targets }\end{array}$ & $\begin{array}{l}\text { Lack of evidence of access to intracellular targets } \\
\text { precludes ADCC as a pathogenic mechanism }\end{array}$ & $\begin{array}{l}\text { Examine whether islet AAbs that target beta cell surface } \\
\text { proteins exist }\end{array}$ \\
\hline $\begin{array}{l}\text { B cells can take up, process and } \\
\text { present islet antigens to T cells }\end{array}$ & $\begin{array}{l}\text { B cells cannot prime autoimmunity } \\
\text { B cells may differ from DCs in the } \\
\text { peptides they process and present to T cells }\end{array}$ & $\begin{array}{l}\text { Examine the antigen-presenting function of B cells with } \\
\text { surface Ig specific for islet autoantigens } \\
\text { Examine the spreading of B cell specificity over time and its } \\
\text { relationship to T cell specificity and disease progression }\end{array}$ \\
\hline $\begin{array}{l}\text { B cell deficiencies do not protect } \\
\text { from developing T1D }\end{array}$ & B cells may not have an essential pathogenic role & $\begin{array}{l}\text { Examine disease heterogeneity e.g. B cell-independent vs B } \\
\text { cell-dependent T1D }\end{array}$ \\
\hline $\begin{array}{l}\text { B cell-targeting therapy } \\
\text { (rituximab) showed a beneficial } \\
\text { effect in T1D }\end{array}$ & Mechanisms of the effect remain unknown & $\begin{array}{l}\text { Systematic analysis of responder/non-responder phenotypes } \\
\text { and disease heterogeneity }\end{array}$ \\
\hline
\end{tabular}

AAbs, autoantibodies; ADCC, antibody-dependent cell-mediated cytotoxicity; Breg, regulatory B cell; DC, dendritic cell; IA-2, islet antigen-2 autoantibody; T1D, type 1 diabetes; Treg, regulatory T cell; ZnT8, zinc transporter 8

transmission of antibodies transfers diabetes from seropositive mothers to offspring in NOD mice, whereas in humans, if anything, it protects offspring from developing type 1 diabetes $[9,10]$. A further anomaly that argues against an essential role for B lymphocytes in clinical type 1 diabetes is the report of an individual with X-linked agammaglobulinaemia and complete B lymphocyte deficiency who still developed type 1 diabetes. Although this reflects a single case, as a clinical observation it shows that both islet autoantibodies and antigen-presenting B lymphocytes are dispensable in the human pathogenesis of type 1 diabetes [11].

In this edition of Diabetologia, Willcox et al investigated pancreatic lymph nodes in recent-onset type 1 diabetes, as these are critical sites for the initial interaction between islet autoantigens and autoreactive lymphocytes [12]. This pioneering study showed a decrease in secondary follicle and germinal centre frequencies in donors with recent-onset type 1 diabetes compared with control donors and donors with longstanding type 1 diabetes. This phenomenon was unrelated to the presence of insulitis or the age at diagnosis of type 1 diabetes. Primary follicles in individuals with recent-onset type 1 diabetes proved structurally less distinct and more diffuse, with poor differential localisation of the $\mathrm{B}$ and $\mathrm{T}$ cell subsets. Type 1 diabetic donors also had more primary follicles that were lacking follicular dendritic cell networks than donors without diabetes or individuals with longstanding disease. This finding may seem surprising if a role for B lymphocytes is considered to be critical in this disease. In their study, 
Willcox et al interpreted the data assuming a pathogenic role for B lymphocytes in type 1 diabetes ('fire') [12]. However, fewer follicular dendritic cells would imply less antigen presentation to B lymphocytes as these cell types are co-dependent, possibly pointing to impaired B lymphocyte activation. Nonetheless, the authors appreciate the large void to be filled concerning the understanding of the B lymphocytic role in type 1 diabetes.

\section{B lymphocytes in type 1 diabetes}

B lymphocytes can be detected in severe cases of insulitis. 'B cell insulitis', however, is perhaps a misnomer since B lymphocytes are always outnumbered by $\mathrm{T}$ cells (especially $\mathrm{CD}^{+}$cytotoxic $\mathrm{T}$ cells). B lymphocytes are reported to be present in small numbers in early insulitis but are recruited to islets as beta cell death progresses, suggesting that they are a consequence, rather than cause, of insulitis [13]. B lymphocytes take up and process antigens in a concentration-dependent manner and are more than a thousand times less efficient than dendritic cells at presenting antigens if they do not happen to express the $\mathrm{B}$ cell receptor for a particular islet autoantigen [14]. For B lymphocytes to get involved, they must first be activated by $\mathrm{T}$ cells that are primed prior to seroconversion. In contrast, B lymphocytes cannot prime naive $\mathrm{T}$ cells, implying that autoantibodies are always a consequence of an earlier loss of immune tolerance to beta cells that is T cell mediated. It seems unlikely, therefore, that B lymphocytes initiate the autoimmune process but the door for a pathogenic contribution remains ajar.

B lymphocytes and dendritic cells may also differ in the islet peptides they present. For example, as processed and presented by dendritic cells, the HLA-DR peptidome differs from that presented by B lymphocytes, specifically for preproinsulin (PPI) and islet antigen-2 autoantibody (IA-2), even when B lymphocytes are engineered to selectively take up these antigen $[15,16]$. This may point to a role for $\mathrm{B}$ lymphocytes in the later stages of type 1 diabetes-associated autoimmunity. Through epitope spreading, B lymphocytes might increase the rate and range of islet autoimmunity and increase the risk for the development of type 1 diabetes, implying a secondary, rather than primary, role in the pathogenesis of this disease.

\section{Islet autoantibodies and their possible function}

What about the main secreted products of terminally differentiated B lymphocytes, the antibodies? At the time of clinical diagnosis of type 1 diabetes in humans, more than $90 \%$ of individuals present with at least one of the type 1 diabetes-associated islet autoantibodies [17]. Despite their presence, no direct diabetogenic role has yet been assigned to these autoantibodies, in spite of their outstanding function as predictive and diagnostic biomarkers ('smoke', rather than 'fire'?) [18]. With a 3\% prevalence of diabetes-associated islet autoantibodies in the general population vs a $0.3 \%$ prevalence of type 1 diabetes, $90 \%$ of seropositive individuals remain healthy $[11,19]$. The relatively low proportion of seronegative diagnoses of type 1 diabetes may, in part, be a consequence of overrating the role of islet autoantibodies in the disease, thereby disqualifying bona fide type 1 diabetes as type 2 diabetes just because of seronegativity. As a consequence, type 1 diabetes may be misdiagnosed by false negative islet autoimmunity, underscoring the urgency of defining the exact role of antibodies in type 1 diabetes. Of note, several islet autoantigens have been reported that are not recognised by autoantibodies, e.g. islet-specific glucose-6-phosphatase catalytic subunit-related protein (IGRP) [20].

Curiously, all currently known B lymphocyte epitopes occur intracellularly in beta cells, precluding antibody-dependent cell-mediated cytotoxicity (ADCC), and thus eliminating these antibodies as directly cytolytic (and diabetogenic) against beta cells. Another potential issue with regard to islet autoantibodies is the inverse correlation between islet autoantibody concentrations and $\mathrm{T}$ cell proliferation in type 1 diabetes that has been observed in some studies, suggesting that individuals with high antibody titres may have low $\mathrm{T}$ cell proliferation and vice versa $[21,22]$. Given the unambiguous, central role of T cells in the destruction of the insulin-producing beta cells [23-28], autoantibodies might even function as surrogates of attempted immune regulation ('ice water'). This provocative concept is corroborated by the finding of an overlap between $\mathrm{B}$ and $\mathrm{T}$ cell epitopes that are associated with anti-inflammatory IL-10 production [29]. Another intriguing observation further supports the concept that impaired B lymphocyte regulation, rather than pathogenic B lymphocytes, influences type 1 diabetes: notably, a lack of anti-idiotypic antibodies to glutamate decarboxylase, rather than the presence of the corresponding autoantibodies, defines type 1 diabetes [30].

\section{B lymphocytes and autoantibodies in immunotherapy}

Immunotherapies targeting (auto)antibodies, such as plasmapheresis and intravenous immunoglobulin replacement (IVIG), as a primary treatment for type 1 diabetes, have had negligible effects on disease [31,32]. Autoantibody titres rarely correlate with clinical remission in immune intervention studies, suggesting that islet autoantibodies play a minor role, at best, in relapse or remission of type 1 diabetes [33]. In contrast, B lymphocyte-targeting therapy, using rituximab, did show a clinical effect, delaying loss of beta cell function over a period of 8 months, albeit in a small group of individuals with type 1 diabetes (primarily adolescents) [34]. Post hoc studies showed that rituximab delayed the fall in C-peptide in type 1 diabetes 
but did not appear to fundamentally alter the underlying pathophysiology of the disease, nor did it induce immune tolerance [35]. These data may indicate that B lymphocytes are pathogenic but could also be explained by a general immunosuppressive role of rituximab that is not limited to B lymphocytes. Another possibility is that, through the decline in B lymphocytes, a niche was created for repopulation of regulatory $\mathrm{T}$ cells (Tregs) or regulatory B lymphocytes [36]. Indeed, extensive phenotypic analysis of blood cells revealed transitional B lymphocytes as the single correlate of clinical efficacy of rituximab [37]. This latter finding could point to an immunoregulatory role for B lymphocytes in the pathogenesis of type 1 diabetes ('smoke'), rather than painting them as a pathogenic immune cell ('fire'), which is in accordance with the finding that type 1 diabetes may develop in spite of B lymphocyte deficiency.

\section{Conclusion}

In spite of many years of study, and notwithstanding the value of islet autoantibodies to predict development of type 1 diabetes, compelling evidence favouring B lymphocytes or islet autoantibodies in the immunopathogenesis that leads to beta cell destruction is still lacking. Given the function of B lymphocytes and antibodies in immunity and other autoimmune diseases, this is a striking notion that begs for validation or dismissal. Opportunities exist to settle the controversy around the role of B lymphocytes and islet autoantibodies. For instance, studying islet antigen-specific B lymphocytes will elucidate any role for B lymphocytes in autoantigen presentation. The study by Willcox et al in this issue of Diabetologia underscores differences in germinal centres between individuals with recent-onset type 1 diabetes compared with individuals without diabetes or, indeed, longstanding type 1 diabetes, and points to the need for a better understanding of the role of B lymphocytes in the pathogenesis of type 1 diabetes. Since preclinical animal models and humans differ in this regard, novel models of disease are necessary for proper translation into immunotherapeutic strategies. The report by Willcox and colleagues underscores the value of immunohistochemical studies on the tissues of donors with diabetes, such as those from the Network for Pancreatic Organ Donors with Diabetes (nPOD; www. jdrfnpod.org) that were used in this study. Studies like these may be useful in guiding the diabetes research community in the design of experiments that unambiguously define whether B lymphocytes function as fire, smoke or, perhaps, ice water in the underlying disease process that causes type 1 diabetes.

Funding The authors are supported by the JDRF, The European Commission, the Dutch Diabetes Research Foundation and Stichting Diabetes Onderzoek Nederland (DON). BOR is the Director of the Wanek Family Project on Type 1 Diabetes (City of Hope, Duarte, CA, USA).
Contribution statement Both authors were responsible for drafting the article and revising it critically for important intellectual content. All authors approved the version to be published.

Duality of interest The authors declare that there is no duality of interest associated with this manuscript.

\section{References}

1. Wong FS, Hu C, Xiang Y, Wen L (2010) To B or not to B-pathogenic and regulatory $\mathrm{B}$ cells in autoimmune diabetes. Curr Opin Immunol 22:723-731

2. Edwards JC, Szczepanski L, Szechinski J et al (2004) Efficacy of B cell-targeted therapy with rituximab in patients with rheumatoid arthritis. N Engl J Med 350:2572-2581

3. Serreze DV, Fleming SA, Chapman HD, Richard SD, Leiter EH, Tisch RM (1998) B lymphocytes are critical antigen-presenting cells for the initiation of T cell-mediated autoimmune diabetes in nonobese diabetic mice. J Immunol 161:3912-3918

4. Noorchashm H, Noorchashm N, Kern J, Rostami SY, Barker CF, Naji A (1997) B cells are required for the initiation of insulitis and sialitis in nonobese diabetic mice. Diabetes 46:941-946

5. Holz A, Dyrberg T, Hagopian W, Homann D, von Herrath M, Oldstone MB (2000) Neither B lymphocytes nor antibodies directed against self antigens of the islets of Langerhans are required for development of virus-induced autoimmune diabetes. J Immunol 165:5945-5953

6. Roep BO, Atkinson M (2004) Animal models have little to teach us about type 1 diabetes: 1 . In support of this proposal. Diabetologia 47:1650-1656

7. Roep BO, Atkinson M, von Herrath M (2004) Satisfaction (not) guaranteed: re-evaluating the use of animal models of type 1 diabetes. Nat Rev Immunol 4:989-997

8. Mestas J, Hughes CC (2004) Of mice and not men: differences between mouse and human immunology. J Immunol 172:27312738

9. Greeley SA, Katsumata M, Yu L et al (2002) Elimination of maternally transmitted autoantibodies prevents diabetes in nonobese diabetic mice. Nat Med 8:399-402

10. Koczwara K, Bonifacio E, Ziegler AG (2004) Transmission of maternal islet antibodies and risk of autoimmune diabetes in offspring of mothers with type 1 diabetes. Diabetes 53:1-4

11. Martin S, Wolf-Eichbaum D, Duinkerken G et al (2001) Development of type 1 diabetes despite severe hereditary Blymphocyte deficiency. N Engl J Med 345:1036-1040

12. Willcox A, Richardson SJ, Walker LS, Kent SC, Morgan NG, Gillespie KM (2017) Germinal centre frequency is decreased in pancreatic lymph nodes from individuals with recent-onset type 1 diabetes. Diabetologia. doi:10.1007/s00125-017-4221-7

13. Willcox A, Richardson SJ, Bone AJ, Foulis AK, Morgan NG (2009) Analysis of islet inflammation in human type 1 diabetes. Clin Exp Immunol 155:173-181

14. van Lummel M, van Veelen PA, de Ru AH et al (2016) Dendritic cells guide islet autoimmunity through a restricted and uniquely processed peptidome presented by high-risk HLA-DR. J Immunol 196:3253-3263

15. Peakman M, Stevens EJ, Lohmann T et al (1999) Naturally processed and presented epitopes of the islet cell autoantigen IA-2 eluted from HLA-DR4. J Clin Invest 104:1449-1457

16. Arif S, Tree TI, Astill TP et al (2004) Autoreactive T cell responses show proinflammatory polarization in diabetes but a regulatory phenotype in health. J Clin Invest 113:451-463 
17. Demeester S, Keymeulen B, Kaufman L et al (2015) Preexisting insulin autoantibodies predict efficacy of otelixizumab in preserving residual beta-cell function in recent-onset type 1 diabetes. Diabetes Care 38:644-651

18. Ziegler AG, Rewers M, Simell O et al (2013) Seroconversion to multiple islet autoantibodies and risk of progression to diabetes in children. JAMA 309:2473-2479

19. Bingley PJ, Bonifacio E, Gale EA (1993) Can we really predict IDDM? Diabetes 42:213-220

20. Roep BO, Peakman M (2012) Antigen targets of type 1 diabetes autoimmunity. Cold Spring Harb Perspect Med 2:a007781

21. Roep BO, Duinkerken G, Schreuder GM, Kolb H, de Vries RR, Martin S (1996) HLA-associated inverse correlation between T cell and antibody responsiveness to islet autoantigen in recent-onset insulin-dependent diabetes mellitus. Eur J Immunol 26:1285-1289

22. Harrison LC, Honeyman MC, DeAizpurua HJ et al (1993) Inverse relation between humoral and cellular immunity to glutamic acid decarboxylase in subjects at risk of insulin-dependent diabetes. Lancet 341:1365-1369

23. Coppieters KT, Dotta F, Amirian N et al (2012) Demonstration of islet-autoreactive CD8 T cells in insulitic lesions from recent onset and long-term type 1 diabetes patients. J Exp Med 209:51-60

24. Roep BO (2013) Beta-cells, autoimmunity, and the innate immune system: "un menage a trois"? Diabetes 62:1821-1822

25. Zaldumbide A, Alkemade G, Carlotti F et al (2013) Genetically engineered human islets protected from CD8-mediated autoimmune destruction in vivo. Mol Ther 21:1592-1601

26. Skowera A, Ellis RJ, Varela-Calvino R et al (2008) CTLs are targeted to kill beta cells in patients with type 1 diabetes through recognition of a glucose-regulated preproinsulin epitope. J Clin Invest 118:3390-3402

27. Lampeter EF, Homberg M, Quabeck K et al (1993) Transfer of insulin-dependent diabetes between HLA-identical siblings by bone marrow transplantation. Lancet 341:1243-1244
28. Keymeulen B, Vandemeulebroucke E, Ziegler AG et al (2005) Insulin needs after CD3-antibody therapy in new-onset type 1 diabetes. N Engl J Med 352:2598-2608

29. Weenink SM, Lo J, Stephenson CR et al (2009) Autoantibodies and associated $\mathrm{T}$ cell responses to determinants within the 831-860 region of the autoantigen IA-2 in type 1 diabetes. J Autoimmun 33: $147-154$

30. Oak S, Gilliam LK, Landin-Olsson M et al (2008) The lack of antiidiotypic antibodies, not the presence of the corresponding autoantibodies to glutamate decarboxylase, defines type 1 diabetes. Proc Natl Acad Sci U S A 105:5471-5476

31. Colagiuri S, Leong GM, Thayer $Z$ et al (1996) Intravenous immunoglobulin therapy for autoimmune diabetes mellitus. Clin Exp Rheumatol 14(Suppl 15):S93-S97

32. Orban T, Kis JT (2011) Prevention of type 1 diabetes mellitus using a novel vaccine. Ther Adv Endocrinol Metab 2:9-16

33. Tooley JE, Herold KC (2014) Biomarkers in type 1 diabetes: application to the clinical trial setting. Curr Opin Endocrinol Diabetes Obes 21:287-292

34. Pescovitz MD, Greenbaum CJ, Krause-Steinrauf H et al (2009) Rituximab, B-lymphocyte depletion, and preservation of beta-cell function. N Engl J Med 361:2143-2152

35. Pescovitz MD, Greenbaum CJ, Bundy B et al (2014) B-lymphocyte depletion with rituximab and beta-cell function: two-year results. Diabetes Care 37:453-459

36. Mauri C, Bosma A (2012) Immune regulatory function of B cells. Annu Rev Immunol 30:221-241

37. Herold KC, Pescovitz MD, McGee P et al (2011) Increased T cell proliferative responses to islet antigens identify clinical responders to anti-CD20 monoclonal antibody (rituximab) therapy in type 1 diabetes. J Immunol 187:1998-2005 